\title{
제2회 ODA 서울 국제컨퍼런스 결과
}

\section{I . 기본사항}

\section{1. 행사개요}

행ㅇ 사 명

: 제2회 공적 개날원조 (ODA) 서울 국제회의

The 2 nd Seoul ODA Inlernalional

Conference

- 행사주제

: 새천 년개발목표(MDGS) 중간 펑가와 원조 효과성 제고

Achieving the MDGs : Mid-term Progress Review and Aid Effectiveness

- 일시 및 장소 : 2008. 6. 3(화) 08:30 18:10, 웨스틴조선호텔, 그랜드볼룸
- 추진기관 : 외교통상나 주최. KOICA, 유엔 한국협회 주관

- 참석자 : 사회 1, 의장 3 , 발표8, 토론 10 덩 등 일반 국내외 참석자 637 명

\section{2. 개최배경}

- 국제사회는 MDGs 달성을 위해 개발원조 (ODA) 확대와 질적 제고를 위해 많은 노력을 경주중이나 지역번로 개반격차와 이로 인해 파생되는 박탈감 내지 소외감은 세계의 공동 번영에 많은 근본적인 장애가 되고 있다. 즉, 2015년을 기한으로 전세계적 개반 화두로 부 각된 $\mathrm{MDG}$ 달성을 위해 설성된 $\mathrm{MDGs}$ 목표 달성을 위해서는 아직 갈 길이 요원한 젓이 사 실이다. 
- 우리나리는 현재 유엔 사부총장직에 진출하였 고, 경세력에 상응한 적극적 익할을 국세사회 로부터 요청 받고 있다. 이번 회의는 튼히, 유 엔이 주창하는 MDGs 달성이 그 어느 때보다 전세계적 현안으로 니각되었고, 우리 정비가 2010년 개발원조위원회(DAC) 가입을 추진하 고 있는 시점이어서 그 의미가 더욱 크다. 이리 한 점을 감안, 한국정니도 원조규모의 확대, 원 조시스템의 혁신, 원조효과의 제고를 통해 $\mathrm{MDGs}$ 달성을 위한 국제사회의 노력에 적극 동찹하고 있다.

- 올해에는 $\mathrm{MDGs}$ 의 달성 현황을 되싶어 보고, 개발원조의 효과성 확보 방안과 지속가능한 발 전, 고용믄제 등 개반과 관련된 주요 글로번 이 슈들에 대해 논의하고자 한다. 특히 이번 논의 를 통해 주요 공여국으로 성장해 나가는 우리 원즈추진체제를 다시 한 번 점검하고, 국제사 회와 공동의 목표를 효과적으로 추구해 나갈 수 있는 구체직인 방법론도 모색해 나갈 예징 이다.

- 한국은 국제사회에 잘 알려진 "빈곤되치국"이 지만, 개도상국과 국제사회의 MDGs 달성을 위해 "빈곤치료국"으로 서듭나고 있다. 이번 행 사는 다양한 국제기구 및 주요 원조국으로부터 $\mathrm{ODA}$ 관계자 낓 전문가늘을 대거 초청, 국제사 회의 원조정책 논의에 크게 기여하는 천퍼런스 가 될 것으로 기대된다. 이 기회를 통해 지구촌
의 기이와 빈곤퇴치 등 지구적 개발문제에 대 해 전문적이고, 진지한 토론이 벌어질 것이며, $\mathrm{MDGs}$ 에 대한 일반 국민의 이해를 높이고, 현 재의 국제개발협력에 대한 개선점도 모색하는 좋은 계기가 될 것으로 기대된다.

\section{II . 세션별 발표 - 토론 요지}

\section{1. 제 1 세션 : MDGs 중간평가와 그 과제}

- Bernard Pelil (EU 개반총국 부총국장)

"MDGs 달성 : 수사에서 행동으로"

(Achieving the MDGs : From Rhetoric to Aclion)

- 식량위기, 기후변화 등으로 인해 MDGs달성 이 위협을 받고 있는 현상황에시 2008년도 는 아크라회의. 뉴욕회의, 도하회의 등 중요 한 회의들이 개최되는 중요한 해임. 그러나 더 중요한 것은 논의사항의 이행여부

- MDGs달성에의 첫 번째 도전은 재원확보인 데, 부역장려, 농업분야 등의 지원이 중요하 며, 약속 이행이 가장 핵심적 사안임. 그러나 현재 $\mathrm{DAC}$ 회원국은 몬테레이 신언을 충분히 이행하지 않고 있으며 원조규모도 $8 \%$ 이상 감축되었고, $\mathrm{ECC}$ 도 처음으로 원조규모가 감 소된 것은 신망스러운 상황 
- MDGs달성에의 두 번째 도전은 원조체제의 제고 필요성인데, 원조체계가 복잡, 다양해 짐에 따라 수원국의 주인의식을 위한 예축가 능성이 저하됨. 일례로, 케냐에서는 20 여개 공여국이 13 개의 조달기관을 동해 의약품을 구입하고, 탄자니아에서는 보건분야에 600 여개의 프로젝트가 진행 중이임. 이는 원조 효과성 저하를 초래

- EU는 아크라회의에 다음과 같은 4가지 측면 을 기대

- 공여국 간의 분업

- 예산지원 및 사업의 활성화

- 결과중심의 관리

- 원자의 예측가능성

- 수원국의 주인의시을 저해하는 다양한 종류 의 자금난반을 중지하고 파리선언에 기반을 두고 우선순위ㅇㅔㅔ 따라 사업이 춪진되어야 함 을 경고함. 또한 빈곤하고 취약한 국가들의 지지 없이는 코펜하겐 협정이 부용지눌이 될 것이므로 지금까지의 협정을 이행, 추가적인 지원이 필요

- Bruce Jenks (UNDP 사무차장보) 주제발표 "MDGs 중간평가와 향후 전망"

(Mid-term Review of the MDGs and Future Perspective)
- 첫째, 세계를 변화시키고자 하는 희망은 현 실이 될 수 있으며, 일례로 한국이나 사하라 이남 국가 중 다수는 빈곤해소와 삶의 질 향 상을 위한 노력의 성공사례임. 이러한 성공 은 신중하게 구성된 프로그램 및 정니의 강 한 리더삽과 국제사회의 지지를 기반으로 한 좋은 정책늘로 인한 것임.

- 둘째, 우리는 빈부격차가 증대하는 등 해견 해야 하는 도전과제를 많이 가지고 있으머, 사하라이남에서는 2015 년까.지 $\mathrm{MDG}$ 를 달성 할 수 있는 국가가 하나도 없는 신정임. 이러 한 맥락에서 2008년은 지금까지 한 공약들 을 다짐하는 중요한 해가 될 것이며, 야속들 을 행동으로 옮기는 것이 관긴. 한국은 항공 권연대기금을 도입함으로써 원조약속을 이 행한 선례가 됨.

- 셋째, 기후변화, 식량윆기와 같은 새로운 이 슈들로 인해 MDGs달성을 향한 행로에서 이 탈될 것이 우려됨. 새로운 이슈늘은 MDGs달 성과 동전의 양면과 같은 존새이며, 특히, 기 후변화는 남과 북이 분업을 통해 해결해야 하 는 분제임.

- 넷째, 민간부문이 MDGs달성에 기여하도록 권장하고 적극적인 참여를 유도하는 것이 숭 요함을 강조. 이를 위해, 민간너문의 관심을 유반, 빈국에의 투자를 촉진시킨 수 있는 환 
겅을 조성해야 함. 이와 관련하여, 08.9 월에 $\mathrm{UNDP}$ 주새로 뉴욕회의를 개최해 비즈니스 모델을 강구하고 새로운 사업기회를 모색하 는 등의 논의를 할 예정. 개도국에 대한 민간 보문이 투자를 늘리는 것은 양쪽 모두에 이 익이 되는 비즈니스 모델이 될 수 있음.

- 다섯째, MDGs달성을 위한 다자주의의 익할 은 양자주의로 대체할 수 없으며, 21세기 당 면과제 해결에 있어서 신흥공어국의 참어가 요구되는 바, 다자주의는 다양한 공여주체들 의 참여를 증진시키는 데에 중요한 억할을 담당할 것임.

- Stephen Groff (OECD 개발국 부국장) 주제발포 "MDGs 달성과 재원확보를 위한 국제사회의 노력" (International Effort for Achieving the MDGs and Expanding Resources)

- 연결성과 상호연계성이 퐆아지고 있는 세계 속에서 개발협력은 전략적으로 변화하고 있으 며, 도덕적 의무 뿐 아니라 각국의 이해가 증 진되고 있으며, $\mathrm{OECD}$ 는 해결도구를 가지고 있기 때눈에 개발협력에 더욱 참여해야 함.

- 세계직인 경제성장 둔화 등 여타 이유로 인 해 각국의 $\mathrm{ODA}$ 실적이 감소하고 약속을 불 이행 하는데 이에 대한 각성 요망. 공여국들 은 2010년 목표를 달성하기 위하여 특히 대
이프리카 지원을 확대해야 할 것임.

- 원조의 예촉가능성을 향상시키기 위해서 OFCD 는

- 원조규모 확대의 효과를 극대화하기 위해 서 국가수준에서 미래지불의사를 밝히는데 장애가 되는 것늘을 제기하는데 일조할 것 이며,

- 파리21을 통해, 좋은 통계자류를 제공하여 개발정책설계와 MDGs 달성을 돕고자 함. 예측가능성의 항상은 원조효과성을 제고하 고 원조사업에 대한 국민의 지지를 확보하 는 동력이 뇔 것임.

- Sarah Cliffe (세계은행 동아시아 국장) 패녈 토론

- 베트남은 개반협력의 결과 빈곤층 수가 전반 이상 감소한 성공사녜로, 그 원인을 살펴보 있을 때, 1)정부의 강력한 리더삽, 공여국들 에 부합하는 전략과 프레임웍을 갖추고 결과 물을 내려고 하는 약속 및 의지, 2)공여국과 긴밀한 협력관계, 3)빈곤감소와 사회직 서비 스에서 국가기관늘이 발전을 주도토록 하는 국가시스템 활용 4)수원국에게 재량권을 주 어 각 공여국간 븐업이 이루어지도록 한 짐. 그러나 평균적으로는 혜택은 있었으나 원조 소외계층이 발생 
- 국가 간 MIGs 달성 걱차를 출이기 위해 디 음과 같은 노력 촉구

- 첫째, 약속을 이행함으로써 원조의 예츳가 능성을 향상시키고

- 둘째, 국가 간 원조조정 필요. 특히, 가장 취약한(most fragile) 국가에 원조를 집중 해야 하는데, 이에 실패하면, 성장하고 있 는 다른 개도국들에게도 니ㅈㅓㅓㅇ적인 효과가 있을 것임.

- 셋째, 선텍과 집중을 퉁해 원조의 질 향상

- 넷째, 장기적이고 지속가능한 이행을 위해 지속적인 모멘텀 생성 및 유지

- Torgny Holmgren (스웨덴 외교부 개발국 국장) 패녈토론

- MDGs에 대한 일반적인 설명을 하면서 $\mathrm{MDGs}$ 단성은 개도국과 선진국 공동책임임. $\mathrm{MDG} 1$ (극심한 빈곤과 기아 퇴치)에 대해서 는 지역별이 아닌 국가별 판단이 필요하고, MDG2(초등교육의부화 달성)에 대해서는 지 난 주 코펜하겐에서 개최딘 회의가 열린 바 개신점을 찾고 있으며, $\mathrm{MDG} 3$ (성평등 촉진 과 여성의 힘 층진)에 대해서는 식량위기에 봉착한 현 시점에서 빈국에서는 농업생산성 과 식량생산을 증대시키고자 하는 바 달성가 능성이 높아짐.

- 스웨덴은 원조효과성 제고를 위해 다음과 갇
이 노력하고 있음.

- ODA규모는 국방예산을 초월. ODA/GNP 비율은 약 $1 \%$

- 결과중심의 관리(Managing for results)

- 2007년 수원국의 수를 70개에서 35개로 축소하여 신택과 집중 직용

- 특정분야에 집숭

- 원조의 $50 \%$ 가 다자기구를 통해 집행되는 등 다자적인 전략

- 개발전략을 지속적으로 평가하고 개선하여 국가전략을 개날

- 새로 구성된 의회에서는 새로운 개반전략 을 채택하고 무역, 환경 등을 통한 원조 확 대 노력

- 08.2월 원조백서를 작성하여 6 개의 집중 과제 제시

- 다양한 공여주체가 참여함에 따라 새로운 $\mathrm{ODA}$ 구조가 필요하고, 국세기구들도 새로운 재원통로를 포괼하기 위해 노력할 필요가 있음.

- 김혜경 (지구촌나둠운동 사무총장) 패널토론

- 제 1 회 $\mathrm{ODA}$ 국세회의 개최 후, 지난 1 년간 국 내직으로는 새 정부 출빔, 국외직으로는 유 가상승, 삭량위기, 기후변화, 미얀마 및 중국 자연재해 등 많은 변화가 있었음. 
- 2000년, UN이 MTGS를 수립하였을 초기에 시민사회는 MDGs 달성이 식량, 교육, 건강, 개발에 대한 권리를 현실화할 것으로 기대하 고 환영하였으나. 몇몇 시민사회는 복표가 야심차지 못하다고 비판하였음. MDGs를 달 성하기 위해서는 식량, 보건, 교유, 개발에 대한 전지구적인 인간권리는 개도국과 선진 국 모두의 의무로 지정(reaffirm)해야 함.

- EU 신입회원국은 $\mathrm{EU}$ 회원 의무사항에 따라 $\mathrm{ODA}$ 규모 및 $\mathrm{ODA} / \mathrm{GNI}$ 비율을 놀라울 정도 로 늘렀으나, G8 회원국 중 미국, 인본, 이탈 리아는 ODA/GNI비율이 가장 저조함. G7은 $\mathrm{EU}$ 처럽 $\mathrm{ODA}$ 관련 의무사항을 제정할 것을 촉구함, 뜨한, $\mathrm{DAC}$ 회원국이 $\mathrm{MDGs}$ 단성에 모범적인 역할을 해야 신홍공여국의 원조를 고무시킬 것이며, 그에 따라 개도국의 상호 책임성도 향상될 것임.

- 수원국의 원조역량을 개발하기 위해서는 수 요자 중심의 기술적 원조를 제공하고, 국별 개발우선순위에 따라 원조해야 함.

- 빈곤퇴치를 위해 정부, UN, 국제개발은행의 익할이 중요하지만 시민사회의 협조와 지지 없이는 MDGs 달성이 어려음. 시민사회의 역할의 일례로, 북구(northern countries) 107 여개 국가에 연합체를 갖고 있는 반빈곤 네트워크, Global Call to Action Against
Poverty는 2000 년 G8 정상회닫에서 중요한 억할을 담당하였으며, 남구 각국 정니 (southern countries)가 MDGs 달성을 위해 개발, 채부변제, 공정부역을 위한 재원조달 에 있어 북구의 선진국과 파트너쉽을 유지하 며, 공공책임성(public accountability)을 갖 도록 촉구함.

\section{2. 제 2 세션 : 원조 효과성의 제고}

\section{- 보다 효과적인 MDGs 달성을 위하여}

- Jackie Frizelle (뉴질랜드 국제개반청 부청장) 의장

- 국제사회의 많은 노력에도 불구하고 현재 MDGs 달성의 진전은 느린 편이머, 이에 몬 테레이 선언에서 약속된 추가 재원확보 뿐만 아니라 원조 방식의 효과성 제고가 매우 중 요함.

- 툭히 '원조의 효과성 제고를 위한 파리신 언' 의 실질적 이행이 시급 ※ 원조의 증액 및 효과성 세고를 위한 주 요 장치

(1) 몬테레이(Monterrey) 회담 및 몬테레이 컨센서스('02년)

: 개발을 위한 글로벌 파트너쉽을 위한 정상회담으로, 공여국늘은 2015년까지 원조규모를 GNI의 $0.7 \%$ 까지 확대하고 수원국들은 효과적인 개반재원 활용을 
위한 여리 가지 내부 조치를 취할 것을 약속

(2) 원조효과성 제고를 위한 파리신인

(Paris Declaration on Aid Effectiveness)('05년)

: 파리신언은 국제사회원조의 파편화 (fragmentation)에 대한 심층적 분석을 토대로 명확한 권고사항을 담은 국세적 프레임워크로써 공여국간 원조의 즈화 (harmonization), 원조와 수원국 우선 순위간의 일치 (a lignment), 수원 구의 주 인 의 식 (ownership), 책 임 성 (accountability)과 투몽성 제고를 위한 역량개발 지원 등을 강조

- Adnan Z. Amin (UN체제 수장회의 국장) 주제 발표

“원즈 효과성에시 개반 효과성으로

:유엔 시스템의 역할"

(From Aid Effectiveness to Develo pment Fffectiveness: The Role of The UN System)

- 한국의 ODA관련 노력을 매우 긍정 직으로 평가하며 작년에 이어 서울 ODA컨피런스에 참여하게 된 것을 잉광스럽게 생각함.

- MDGs는 개발을 위해 누가 누엇을 어떻게 해야 한다는 일종의 책임 프네임워크 (accounlabilily framework)를 제시하고,
국제원조의 중심점을 마련했디고 평가

- 국제개발협력을 바라보는 시각이 다양하나 (e.g. 정치적 도구, 구제 등), 개발협력은 궁 극적으로 다자협력의 도구로써 국세사회확 립과 강화에 기여하였고 모든 이해관계자에 게 이득이 되는 활동(enlightened selfinterest)임이 확실

- 최근 들어 시민사회, 양자원조 기관, 기업, 신흥공여국 등 새로운 개날협력 행위자늘이 등장하고 활동의 영역을 넓이고 있으며, 이 는 국제 원조 전달(aid delivery) 및 재원조달 시스텐의 파편화(fragmentation)를 야기하 고 있으며 따라서 이에 대한 개혁이 요구됨.

- 많은 수원국에서 개날원조는 각 공여자가 각 각의 우선순위와 방식으로 무분번하게 원즈 를 제공하는, 즉 '뷔페” (buffet)방식으로 이 루어지는 현실임.

- 이로 인해 특정 부분 원조는 포화상태이고 어느 비눈은 심각한 재원비족을 겪고 있음

- 대부분의 ODA가 세금으로 마련되는 만큼, 공여국 정부가 세금의 수체자인 자국의 국 민들의 요구와 기대에 맞추어 원조를 제공 해야하는 입박을 받고 있으며 국익과 수원 국의 수요간의 균형을 맞추는 일은 매우 큰 도전과세임. 
- 이러한 변화 및 도전과제는 유엔 내에서도 존새

- 유엔은 거대한 개발 mandate를 갖고 있으 나, 시스템의 파편화(fragmentation)와 정 책 및 사업간 불일치(in consistency)가 UN 원조의 효과성을 저해

- 각 유엔 기구늘은 자신의 mandate와 우선 순위대로 개발협력 활동을 펼치고 있으며, 개발'을 전체적으로 이해하고 추진하는 중 앙 거버넌스 시스템이 결여

- 각 기관의 기술적 능력과 전문성을 포괄적 개반 전략으로 전환함이 긴요

- 이와 관련, 2005 년부터 유엔개혁, 특히 개 발협력관련 유엔구조 개혁에 대한 논의가 활반하게 진행 중

- 현재 시범 중인 'One UN at the Country Level' 이니셔티브는 수원국 내에서 UN 기구들의 활동의 조정과 일치를 도모하는 데 목표를 두고 있음.

- 이같은 유엔의 노력과 함께 공여국들은 파 리선언에 언급된 원조조화에 대한 노력을 확대할 필요

- 국제개발사회의 3 대 도전과제로 디음을 선 정하고 문세 해결을 위한 범지구적 노력을 강력히 촉구중

(1) 국제식량위기

- 국세식량위기의 근원은 지난 몇 십년간 전 세계적으로 농업부문을 소홀히 한데
따른 것이며, 특별히 선진국의 잉여 식 량물자가 개도국의 식량원조로 사용되 면서 개도국의 농업분야 투자부족으로 이어지고 농업 생산성의 저하를 야기한 데 있음

(2) 범지구직 보건 문제

- 말라리아, 걸핵, HIV/ATDS 등 질병의 잉향은 아프리차 개발 기반 전체를 위협 하고 있으며 개발 잠재성을 심각히 저해 하고 있음.

(3) 기후변화대응 및 적응

- 기후변화문제는 난로 심화되고 있으며, 특히 소규모 섬 국가들의 생존을 위협

- 현재 기후변화문제는 국가간 의무와 책 임에 대하여 정치적으로 매우 복잡한 관 계에 얼혀 있음

- 그러나 개도국(특히 아프리카 최빈국)은 기후변화를 야기하지 않았으므로 문제 해결에 대한 책임이 없다고 주장하며, 자신들의 기후변화대응 및 직응에 대한 비용을 선진국이 부담할 것을 촉구

- 이와 관련, 국세사회는 기존의 $\mathrm{ODA}$ 를 재배분하는 것이 아니라 새로운 재원확 보를 봉해 기후변화관련 개발원조를 제 공할 필요가 있음.

- 현재 원조효과성에 대한 논의는 대부분 비슷 한 생각을 가진 개발협력 행위사들간 이루어 지고 있음 
- 수원국늘은 공여국의 진의를 의심하는 겅 향이 있으며, 선진국의 조건비 원조와 타이 드 원조에 대한 비판만을 앞세우고 있어 두 그룹 간 협력에 장애를 초래

- 공여국과 개도국간 진솔한 대화기회 마련 과 서로 다른 관점과 이익을 가지고 있는 디양한 행위자늘간 대화 확대 필요

- 특정 분야에서의 원조의 효과성이나 애매모 호한 원조효과성의 ‘도덕성' 만을 논의하는 것이 아니라, 개날을 위한 포괄적인 노력이 긴요

- 특히 무역과 원조의 필연성을 강조하며 국 제농업무여체제 개혁을 촉구

- 무역자유화의 혜택은 국가 무역 경쟁력이 어느 정도 있을 때 누릴 수 있고, 대부분의 개도국은 현재 농업부문에 비교우위를 지님

- 그러나 선진국의 농업보즈정ㅊ책은 개도국의 무억 경쟁력을 심각히 저해시키고 그들의 자립 기회를 박틸

- 따라서 부역 분야 능 여러 분야에 걸쳐 좀 더 동합적이고 실질적인 '개발' 의 정책 필요

- 마지막으로 국제개발협력은 지켜지지 않은 약속의 익사를 가지고 있으며 공여국이 개도 국의 빈곤되치를 위해 기존의 원조 공약을 이행할 것을 촉구

- 특히 고유가 등으로 인한 경제침체로 원조 를 축소하지 않도록 노력해야 하며 위기상
황일 수록 개발협력의 중요성을 강조할 필요

- Matthew Sudders (영국 국제개발부 양자관 계과장) 주세발표

“원조 효과성 : 새로운 신구자"

(Aid Fffectiveness: The New Frontier)

- 영국개반청 $(\mathrm{DFD})$ 이 선립된 지가 10 년이 넘 었음에도 불구하고, 금일과 같이 몇 백 명의 사람들이 모여 ODA에 대해 토론하는 행사 는 처음 참석하며, 서울 ODA 컨피런스를 노ㅍㅗㅡ 이 평가

- 한국 국제개반협력 관련 노력 평가 및 개선 을 위한 제안

- 한국은 개날 원조를 효과적으로 활용한 성 공사례로시 $\mathrm{ODA}$ 의 중요성을 국제적으로 알리는 억할을 감당해야 함.

- 금년에 Non-DAC 국가 중 유일하게 파리 선언의 모니터링에 참여한 것과 $\mathrm{OECD} / \mathrm{DAC}$ 가입 추진 노력을 높게 평가

- 그러나 $\mathrm{ODA}$ 집행 기관이 너무 많으며 $\mathrm{ODA}$ 시스템 개혁과 원조의 언타이드화 노 력을 계속 해 줄 것을 당니

- 아울러 한국의 ODA 규모 확대노력과 향후 추가 재원이 지금까지의 ODA중 가장 효과 성이 높은 ODA가 되도록 노력 필요 
- 피리선언이 공여국 중심의 어젠다라는 지적 은 파리선언의 서명국 중, 선진국보다 개발 도상국의 숫자가 더 믾있다는 사실을 간과한 것이며, DAC회원국이 주도는 했으나 수원국 과의 많은 협의를 동해서 만들어진 합의임.

- 파리신언에 대한 이견이 있다면, 그것이 최 종 녹표에 대한 것인지, 공봉 녹표를 달성 하는데 있어서의 과정(process)에 대한 것 인지를 분명히 하고 실진적이고 긴선적인 논의 유도 필요

- 파리선언은 원조의 효과성 제고를 위해 긴요 하나 충분한 도구는 아님을 강조

- 파리선언은 일부 원조 영역은 포함하지 않 으며, 개반협력의 모든 방면에서 우리 모두 가 어떻게 처신(behave)해야 하는지에 대 한 충분한 가이드라인이라고 볼 수는 없음 - 파리선언은 최소한의 기준 및 가이드라인 으로 이해되어야 적당

- 2008년은 아크라회의, 도하회의 능 국제개발 협력에 있어서 매우 중요한 해라고 강조하고. 각종 국제회의의 합의들이 결과물로 나타나기 위해서는 "약속 추적자" (Fromise Tracker)가 약속 이행을 지속적으로 촉구할 필요

- 영국은 08.9 월에 개최될 Accra 회의에서 원 조의 예측성(predictability)과 상호 책임성 (mulual accoun lability)을 강조할 예정
- 쏭종 공여자늘은 미치 누군가를 고용한디 고 하면서 언세 얼마나 월급을 줄 것이고, 이것을 인제 알려줄지도 가르쳐 주지 읺는 듯 하는 태도를 취하고 있어 수원국에서 많 은 혼선을 야기

- 원조제공 약속 이행에 대한 책임은 자주 논 의되지만, 정작 원조의 효과에 대한 책임에 대한 문제는 종종 간과되는 경향

- 마지막으로 원조의 효과성을 위한 생각의 전 환 및 자세의 변화를 촉구

- 개반협력 실무자들이 국가나 기구 차원의 약속 뿐 아니라 개인적인 책임감을 가지고 본인이 야속한 것을 이행하고 있는지, 또 자신이 추진하려고 하는 일이 본인의 어마 니에게도 쉽게 설명하고 이해뇔 수 있을 만 큽 현명한 것인지에 대한 질문을 종종 던져 보며 실무에 임할 것을 귄고

- 장현식 (전 KOICA 정책연구실장, 현 KOICA 이사) 패녈토론

(Aid Effectiveness : The New Frontier)

- 피리선언에 대해 디른 해석이 존재함

- 08.4월 한일이 공동주최한 Non-DAC 방 콕회의에서 신흥공여국 대표들이 파리신언 이행에 부담을 느끼고 있으며 선언자체를 자신들의 결과물이나 목표로 인식하고 있 지 않음이 관찬됨 
- 08.5 월 OFCD/DAC 고위급 회의에서 많은 수원국들이 파리선언에 회의 적인 입장을 보였음,

- 수원국늘은 피리선언 5 원칙은 어렵고 모호 하다고 생각하며 수원국의 입장보다는 $\mathrm{DAC}$ 신진공여국의 입장을 담고 있다고 이해

- 이울러 수원국의 입장에서 원조의 효과성 제고를 위한 명확한 6개 우선순위(익량개 반, 예측성, 조긴부해제, 원즈분업, 인센티 브창출, 언타이드화)를 제시하였고, 이에 대한 공여 국들의 이해와 지원을 요구

- 파리선언은 매우 의미 있는 개발협력 프레임 워크이지만 공여구의 상황에 따라 신축성 (flexibilily)을 부여할 필오가 있으며, 수원국 의 입장을 반영하여 이해와 이행을 더욱 더 용이하게 할 필요 강조

\section{- Tom Arnold (아일랜드 CONCERN}

WORLDWIDE 회장) 패널토론

- CONCERN WORLDWIDE는 아일랜드에 본부와 30 여 국가에 현지사무소를 두고 약 2 억불의 예산을 가진 국제 $\mathrm{NGO}$ 로서 북한에 도 사업 운잉 중

- 한국의 개발에 대한 이해와 겅험이 현재 개 도국들에게 도움을 줄 수 있다는 것을 강조 하고 한국의 개반경험을 국제사회와 공유해
줄 것을 부탁

- 세계 식량위기의 심각성 증대와 대응방안 긴요

- 식량이기는 전세계 빈곤층의 고동을 삼화 시키고 있으며, $\mathrm{MDGs}$ 달성을 더 어렵게 하고 있음

- 현 위끼는 에너지위기와 기후변화와 관련 되이 있으며, 단시인 내에 해견될 기미가 보이지 않음

- 전 세계 정부늘은 현 위기가 지난 30 년 동 안 농업정책을 경시한 결과임을 인지하고 단기적인 인도적 지원과 함깨 장기적 대처 방안 강구 필요

- 원조의 효과성 제고를 위한 새로운 형태의 파트너십

- 공여국간 부담 공유(burden sharing) (특히 석유 누국들의 개발원조 증대 요망)

- 유엔기구 및 정부와 NGO간의 협력 증대

- 민간부문(전겅련), $\mathrm{NGO}$, 정부 간의 파트너

십 활성화

- 특히 정부는 시민사회의 역할을 보다 더 존 중하고 시민사회는 보다 더 전문적인 아이디 어를 활발하게 제공할 것을 촉구

- Gabriel Ferrero (스폐인 외교누 개발협력기 획정책 부국장) 패널토론 
- 개발도상국의 발전은 민주주의 블 안에서, 정치적인 합의가 있어야 가능하다는 것을 강 조하고, 하부상달식 (bottom-up) 원조와 시 민사회 및 기업의 참여가 중요

- Stefan Leiderer (독일 개발연구소 연구원) 패널토론

- 파리선언은 MDGs단성 및 향후 개반정책방 향 등에 있어서 매우 중요하머 가장 포괄적 인 원칙을 제시하고 있으며 공여국간 협력하 여 국제적 체제에 대한 약속을 한 것으로 반 드시 이행되어야 함.

- 그러나 파리선언 원칙의 개념들이 모호한바 구체적 이행방안 마련이 필요

- 08.9 월에 개최될 아크라회의의 중요성을 재 차 강조

- 원조규모 증대와 효과성 제고에 중요한 모 멘텀이 마련될 것으로 기대

- 단순히 절차에 관한 문세만이 아니라 원조 에 관한 모든 교훈을 종합하여 수원국과 공 여국 모두에게 플러스가 되는 개발협력 방 안을 제시해야 함.

- 원조의 효과성 제고에 있어서 다음과 같은 도전과제가 존재

(1) 정책의 인관성 구축 및 유지
(2) 개발정책에 누가 정봉성을 가질 것인가.

(3) 파리선언의 틀 안에서 해결될 수 없는, 개 별국가간의 글로벌 관계 및 경제직 입장 차이

\section{3. 제3세션 : 원조와 글로벌 이슈}

- 선준영(유엔한국협회 나회장\&CEO) 의장

- $\mathrm{ODA}$ 와 글로벌 이슈의 상호 연관성을 찾는 것이 중요하다고 강조

- ODA가 MDGs의 맥락 하에 추진뇔 때 빈곤 퇴치, 기아감소, 질병퇴치, 보건제고, 교육 확대 등이 가능하며 이는 개도국의 역량 개 발에 궁극적인 도움을 가저다 줄 것임

- $\mathrm{ODA}$ 를 통해 문제를 해견할 때에는 다양한 문세가 상충할 수 있고 따라서 다양한 이슈 에 대한 상호질층방안을 마련하는 것이 중요 한 문제.

- 어떻게 하면 한 분야를 희생시키지 않고 모 두 발전시킬 수 있는가에 대한 논의를 세 번 째 세선에서 중점적으로 다룰 것임

- Koro Bessho (일본 외부성 국제협력국장) 주 세 발표 "기후변화와 개발"

(Climale Change and Developmen l) 
- 추제와 관런된 세 가지 언급

- 기후변화는 여러 지억에 가뭄과 홍수를 야기하고 있고, 튼히 농업분야에 큰 타격을 주기 때문에 식량난을 더욱 가숭시키고 있음

- 개발 문제와 관련하여 글로벌 이슈의 악영 향에 대한 조치가 필요하다는 인식이 증대 되고 있고, 이 조치는 반드시 개발문세와 연계하여 이루어져야 하지만 아직까지는 각 분야의 조화와 노력이 부족한 상태

- 다양한 이슈들 중 기후변화를 국가개날계 획의 인환으로 해견해야 하며 우리는 개도 국을 지원하여 이 문제들을 해결해 갈 수 있도록 도와야 함

- 새천년을 맞이하면서 ADS, SARS, 조류독 감, 테러 등의 다양한 이슈들과 함께 기후변 화 문제가 대두됨에 따라 개도국들이 많은 고통을 감수하고 있음

- 기후변화 문제는 전 지구적, 인간적인 문제 로 인식되기 시작했고 우리는 더 많은 원조 를 제공함으로써 그들을 도와야 함

- 두 가지 분절 상태에 대한 고찰이 필요

- 원조체제의 조화 부족으로 특징한 문제가 대두되면 한곳에만 집중적으로 투자를 하 여 일관된 개발계획 없이 원조가 이루어지 고, 시스템의 교란이 반생
- 인도주의적 구호활동, 개발원조 지원활동, 글로벌문세 등이 모두 다른 국세기구에서 다루어진다는 것이 문제이며 기관이 분화 되어 있기 때문에 책임문제가 발생하고 이 책임의 조화를 이루는 데 어려움을 궊음

- UNDP의 2007 2008년 보고에서는 MDGs가 기후변화에 의해 위협받고 있다 고 명확히 나타남

- 서로 기후변화에 대한 자신의 책임을 회피 하고 제한된 자원을 두고 서로 싸우고 있는 것처럽 보임

- 각각의 글로번이슈와 $\mathrm{ODA}$ 는 상충하기 보 다는 모두 협력해야 함

- 개반과 기후변화가 상빈된 것이 아니라는 인 식이 필요하머 이 둘을 동시에 협력하여 달 성할 수 있음

- 기후문제로 $\mathrm{MDGs}$ 의 단성을 방해하는 것 이 있다면 지금과 같이 방치할 것이 아니라 구체직인 요소를 제거해야 함

- 기후변화는 주로 선진국늘에게 책임이 있 고, 선진국은 개도국이 이 같은 실수를 똑 같이 반보하게 해서는 안 되기 때문에 신진 국은 개도국에게 이 같은 믄제에 슨응할 수 있도록 도와야 함

- 일본은 100 억 달러의 기금으로 개도국에게 기후변화에 대치할 수 있도록 도와수기 위 해 “Cool Earth Partnership”을 제안하였 고 이것을 궁극적으로 받아들이는 문제는 
개도국에게 달려있음

- ODA를 실현함에 있어서 다양한 재원을 확 보하는 데 노력을 기울여야 함

최순홍 (UN 정보통신기술국 사무차장보) 주제 발표 "UN과 ODA : 정보통신기술의 관점" (The United Nations and ODA : An TC,T Perspective)

- UN이 $\mathrm{ODA}$ 사업에 참여한 역사는 매우 김

- UN의 1970 년 총회에서는 ODA규모를 $\mathrm{GNI}$ 대비 $0.7 \%$ 로 늘려 개반도상국을 돕겠 다는 목표를 채택했고 그 후 UN과 많은 공 여국들은 개도국을 지원 하여 원조 사업을 조정하고 이를 효과적으로 산시할 수 있도 록 도움

- 2000 년에는 189 개의 세계 정상들이 모여 서 새천년 개반목표를 채택했고 이는 전 세 계 사람들에게 잉감을 주어 함께 노력하여 빈곤되치를 위해 힘을 모으는 데 기여함

- 그 이후 $\mathrm{ODA}$ 는 MDGs 달성의 주요 재원 으로 고려됨

- 지금 UN 내에서는 가장 빈곤한 사람늘을 놉 는 데 우선순익를 두사는 새로운 개혁운동이 일어님

- UN은 지금까지 국제사회에 다양한 규범과 방법들을 세시해 옴

- 평화유지를 위해 UN의 역할이 중오해짐에
따라 전 세계의 국가늘은 더욱더 UN에 기 대를 걸고 있음

- 인도주의직인 사업과 인권보장을 위한 사 업도 활발하게 전개.

- UN 사무총장은 최고빈곤인구 10 억 명과 사하라이남 아프리카를 위한 ODA사업에 집중하고 있으며 또한 교육, 보건, 지속가 능한 개발과 같은 범지구적인 문세를 주도 적으로 이끌고 있음

- UN은 세계유일의 보편기구로서 모든 국가 들을 아우르며 국가들을 촉진하는 여할을 담당하는 중요한 위치에 있으며 국제사회 의 문제를 범지구적인 수준에서 해결하기 위해 노력할 것임

- 정보통신의 이용도가 증가함에 따라 그 혜택 도 점차 확대되었지만 정보사회의 격차는 국 제사회의 안정을 위협하고 선진국과 빈곤국 의 차이를 더 크게 벌여놓음

- ICT의 정보교환을 통해 국민들은 알권리가 충속되고 정부는 투명성 확보가 가능하기 때문에 TCT는 지속가능한 개발을 촉진하는 데 중요한 역할을 하고 있음

- 현재 국가, 지역, 국제적인 수준에서 TCT의 중요성에 대한 인식이 확산되고 있으며 $\mathrm{ICT}$ 와 $\mathrm{ODA}$ 를 접목하여 효율성을 극대화 해야 함

- ICT를 잔 활용하여 경제사회의 반전을 이룩 
하기 위해 디음의 4 가지사항에 초점을 맞추 어야 함

(1) 전략

- 다양한 분야를 아우르는 TCT가 국가전 락에 적절하게 반엉되었을 때 국가개발 전략이 더욱더 통합될 수 있음

(2) 인적자원

- 인도에서 잉어를 할 수 있는 사람들이 ICT의 반전으로 인해 많은 혜택을 누리 게 된 것과 마찬가지로 국가의 ICT전략 이 적절히 개날되어야 국가의 경제, 사 회적 혜택이 모든 사람들에게 고루 제 공뇔 것임

(3) 기술

- 하드웨어와 소프트웨이의 개념을 강화 시키는 것이 중요

- 컴퓨터가 없는 상태에서는 전 세계 사 람들이 서로 소통하기 힘들기 때문에 하드웨어, 즉 컴퓨터의 중요성을 간과 해서는 안 됨

- 전략, 인적자원, 재원과 같은 소프트웨 어를 뒷받침하기 위해서는 기술 그자체 도 매우 중요한 요소로 작용

(4) 재원확보

- 정니와 비정닌기관들뿐 아니라 기업은 가난한 사람들이 ICT의 혜택을 받을 수 있도록 더욱 노력해야하며, 이러한 방 향으로 사업을 추진해야 함.

- 개반 사업은 수원국으로 하여금 외부지
원에 과도하게 의지하지 않도록 하기 위해 수원국들도 자체적으로 재원을 확 보할 책임을 주어야 함.

- 원조조화는 제한된 재원을 효과적으로 사용 하기 위해서 합리직으로 서로 조정하는 것을 의미.

- 함께 공유하고 있는 목표와 전략 하에 사업 을 추진하여 중복을 피한다면 디욱 효율성 있는 원조를 실현할 수 있을 것임.

- 이러한 원조조화의 노력으로 많은 혜택이 개도국에게 전단된 것이며, ICT가 이러한 네트워크를 강화시킬 것임.

- 정부와 비정부기관들은 ICT의 혜택을 받을 수 있도록 사업구상을 하고 투자를 확대하 여 공동으로 일을 추진하는 것이 필요하머 이를 동해 다자적인 조화의 확대를 기대할 수 있을 뿐 아니라 제한된 원조 자원을 효 과적으로 공유함

- 수원국도 공여국에게만 너무 의지하지 말 고 재원을 마련할 수 있는 자주적 노력을 이끌어 내야하며 ICT를 계기로 수원국과 공여국이 서로 협력할 수 있는 방안을 마련 해야 함

- Milan Vodopivec (세계은행 노동시장딤장) 추제 발표

“고용과 개발 : 저소득 국가의 노동시장 패러 다임을 위하여" 
(Fmployment and Development : Toward a Labor Market Paradigm for Low Income Countries)

- 여러 국가들이 다앙한 개혁을 도모하여 사 회, 경제직 발전을 이룪하기 위해 일자리를 창출 하지만 창츨된 일자리늘은 대부분 저임 금, 저생산성의 일자리들이기 때문에 이러한 경제성장이 빈곤을 타파하는데 근본적인 기 여를 하지 못하고 있는 살정

- 고용이야말로 성장을 빈곤타파로 이어가는 데 중오한 억할을 할 것으로 기대

- GDP에서 근로자들이 받는 임금의 비중이 접차 줄어들고 있을 뿐 아니라 한국을 포함 한 아시아 국가에서 노동 집약도가 점차 줄 어들고 있어 GDP에서 인건비와 노동의 역 할이 줄어듦

- 전 세계에 아직도 상당히 많은 수의 근로자 들이 일을 하고 있음에도 불구하고 하루에 채 1달러도 벌지 못하고 있는 근로빈곤층

- 최근에 늘어서 MDGs의 복표에 고용을 포 함시켰으며 여기서 말하는 고용은 완전하 면서도 고생산성의 일자리, 품위 있는 일자 리를 창출하는 것을 복표로 하는 것임

- 고용을 개발의 맥닥에서 이해할 필요가 있음 에도 이를 추구하기 위해서는 아직도 많은 세약이 따르기 때문에 두 가지를 해결책을 제안
(1) 노동시장의 운영 기본 블인 MIT, $\mathrm{ES}$ 접근법

(2) 축가적으로 개도국에서의 노동시장에 대 한 이해를 도모하기 위한 연구 필요

\section{- 운엉 기본 틀 MILFS}

- Macroeconomics(거시경제), Investment climate(투자 분위기), Tabor market institutions(노동시장세도), Education and skills(교육), Social protection(사회 보장) 이 5 가지 요소를 고려하여 고용 창출 을 증진해야 함

- 이를 위해서는 수요, 공급을 포함한 다양한 부문의 참여가 필수적이며 또한 이 방법은 구속력 있는 제양에 초점을 두어야 함

- 여기서 가장 중요한 것은 이 오소들 중에서 고용창출을 저해하는 가장 큰 요소가 무엇 인지 파악하고 이 요소들을 현재상황의 진 단평가 방법으로 활용하려고 함

- 고용을 창출하는 가장 좋은 전략이 무엇인 지를 파악하기 위해서는 기존에 존재하는 모든 진단 도구를 활용해야 함

-노동은 결코 노동시장만의 문제가 아니기 때문에 다양한 부문의 제도를 살펴봐야 하 며 개발하고 있는 여러 가지 진단도구 중 하나가 현존하는 규정과 법에 대해 연구하 는 것임

- 이를 실행하기 위해서는 국가별로 구체적 인 일자리연구가 필요하며 이 연구를 바탕 으로 지역번로 시범사례를 운영하게 됨 
- MITFS의 요소 중 어느 것이 가장 중요한 요 소인지 그리고 실용적이면서 실효성 높은 세 약문제를 파악하기위해 필요한 7 개 주요 부문 (1) 노동시장에 대한 진단을 개선하고 그 취 약성을 파악.

(2) 투자분위기와 노동수요, 빈곤, 기후변화 간의 연관관계를 피악.

(3) 구조개혁, 세계화의 혜택과 비용에 대해 파악.

(4) 정규직과 비정규직의 차이점을 파악.

(5) 적합한 노동시장의 규정과 제도를 파악.

(6) 개반기순의 최적사례를 파악.

(7) 국제적 이주문제에 대해 파악.

- 이를 신행하기 위한 전략인 다자 공여국 신 탁기금(Multi-Donor Trust Fund)을 마련 하는 목표

- 연구 활동을 강화하는 것

- 억량강화를 도모하기 위해 정책입안자, 연 구원 등에게 기술을 지원할 계획

- 연구를 봉해 실체적인 결과를 가져올 것임

- 고용문제와 개발문제를 통합하기 위해 포괄 적으로 합리적인 노동시장의 패러디임을 구 축해야 하며 이러한 노력을 성공으로 이끌기 위해서는 국제사회의 협력이 질실

- Mary Power (국세기상기구 재원조달국장) 패넌 토론
- 기후문제는 선진국에제 많은 책임이 있음에 도 불구하고 개도국에 책임을 요구해야 하는 상황이 발생함에 따라 집단직 노력이 절실하 게 됨

- 기후 문제는 인간의 생존을 위협하고 있기 때문에 국가차원에서도 기후문제 의 충요성 을 자각해야만 함

- 공여국은 과학적 자료를 바탕으로 수원국이 변화에 잘 순응할 수 있도록 장려해야 함.

- 아직 많은 국가들은 인프라가 부족 하며 환 경문제 해결을 위해서는 보다 더 효과적인 정보 교환과 국가적, 국제적인 투자가 필오

- Yoshiteru Uramoto (UN 공업개날기구 사무 차장) 패널 토론

- 올해 1월말에 AU 정상회담에서는 아프리카 연합과 UNTDO가 같이 협력하여 아프리카 의 산업화에 대한 세션을 마련했고 '지금 산 업화에 대한 논의를 할 여력이 있는가'에 대 한 질문에 이렇게 인본적인 문제에 산업화를 언급하지 않을 수 없고, 또한 산업화야 말로 평화를 위해 반드시 필요한 요소라고 생각함

- 이세 사람들은 더 이상 1달러, 2 달러의 소득 은 신경 쓰기보다 대신 많은 부의 창출을 원 
하기 때분에 지금까지 강조해 왔던 "빈곤퇴 치”의 개넘은 “누-의창출" 로 다시 생각해야 함

- MTGs의 숭간평가 시점에서 우리는 복표롤 포기할 것이 아니라 조정을 해서 최빈국 (LDCs) 10 억 인구에 좀 더 집중할 필요가 있음

- 어느 정도 기반을 잡고 나서야 다음단계로 나아간 수 있지만 최빈국의 전빈정도는 $\mathrm{MDGs}$ 에 대한 준비도 되어있지 않은 상태이 기 때문에 최빈국이 인프라를 구축할 수 있 도록 도움을 주는 것이 무엇보다 중요

- 산업 인프라를 구축하면 파급효과를 발휘해 다양한 분야에서 이득을 볼 수 있기 때문에 우리 모두가 협력하여 개발이 지속가능 하도 록 경제활동, 산업화에 집중적인 관심을 가 져야 함

- Stephen Groff (OECD 개빌국 부국장) 패널 토론

- 1980년 이후 농업에 대한 원조가 감소하고, 대규모 농촌 기업의 실패, 곡물 생산의 증가 로 인한 가격 하락 등 기논 사업 서비스에서
농업이 상대적으로 배제되어 왔으며 식량 위 기와 관련한 최근 보고에 따르면 농촌 지억 의 9 억 명이 공촌 빈곤을 겪고 있음

- 농업분야에 대한 투자 감소는 최근의 곡물 가격 상승의 원인이 되고 있으며 세계은행은 식랑 문제 해걸을 위해 비료, 살충제 사용 축 소와 함께 보조금은 시장을 왜곡시키는 결과 를 내기 때문에 선진국의 농업 분야 보즈금 을 감소시켜야 한다고 보고 있음

- 2006년 OECD/DAC는 '농업이 빈곤 인구에 어떻게 사용뇔까 와 관련한 보고를 발표

- 시량 원조가 제대로 실시되었을 때 인명을 구할 수 있고 다양한 개반을 촉진할 수 있 지만 만약 식량원조가 제대로 이루어지지 않는다면 오히려 역효과를 일으킬 것임

- 2 년간의 식량 가격 폭등은 빈곤국에게 큰 피해를 주었고 따라서 단기적인 식량 원조 를 대폭직으로 확대해야 함

- 개도국에 식량 제공이 원활이 이루어질 수 있도록 단기적인 식량 원조를 대폭적으로 확대해야 하며 개도국 스스로는 자국의 홍 업 정책을 다시 검토해야 함 


\section{『국제개발협력 논문 기고 안내}

한국국제협력단은 계간지「국제개발협력」에 게재할 원고를 모집하고 있습니다. 주제는 국제 개발협력 관련이슈중 아래에 정한 내용이어야 하나. 이외에도 최근 국제사회 및 우리나라에 서 논의되는 국제개발협력 관련 주제도 환영합니다. 우리나라 국제개발협력의 발전과 국제개 발협력에 대한 국민의 인식 제고를 위해 국제협력 종사자 및 국제협력에 관심있는 많은 분들 의 투고를 기대합니다.

\section{1.『국제개발협력』발간목적}

「국제개발협력」은 공적개발원조(ODA) 관련 이슈 뿐만 아니라 제3세계 개빌과 관련한 모든 제반 분제에 대한 이론과 정책대안을 모색하고 관련 자료를 제공하는 데 그 복적이 있다. OFCD/DAC 를 중심으로 국세사회에서 논의되고 있는 세 3 세계 개발 관련 이슈들을 알리고 이에 대한 우리가 나아가야 할 방향을 ․ㅗ색하는 장이 되도록 하겠다.

2. 국제개발협력』 원고 게재 절차

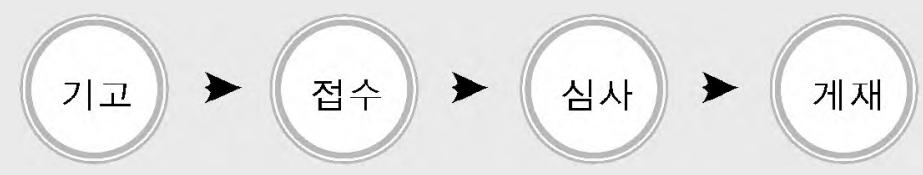

\section{1) 기고 및 접수}

- 기고 및 접수는 $\mathrm{e}-\mathrm{mail}$ 전송을 원칙으로 하머, 불가피한 경우 우편으로도 접수할 수 있다. 단, 우편접수 시에는 논문의 원본 파일이 저장된 플로피 디스켓 혹은 CD 1매를 동봉한다.

주소 : (461-833) 경기도 성남시 수정구 대왕판교로 418 한국국제협력단 정책연구실 e-mail : calliorpapers@koica.go.kr

Tel : (+82)31-740-0301 Fax: (+82)31-740-0681

- 원고 접수는 각 호의 원고 마감일에 따른다. 


\begin{tabular}{|c|c|c|}
\hline 호 & 기 고문 주제 & 원고 마감일 \\
\hline 2008년 제3호 & $\begin{array}{l}\text { I1 원조 효과성을 위한 파리선언, 다자간 원조의 효과성 } \\
\text { - 예시: 원조효과섬 제고를 위한 우리의 대 응방인, 다자간 원조의 효과섬 제 고 방인 }\end{array}$ & 2008.10 .31 \\
\hline 2008년 제4호 & $\begin{array}{l}\text { - Aid \& Environment, Aid for Trade } \\
\text { - 예시: UN기후변화회의와 기술협력. 개 도국의 무역멱량제고를 위한 원조의 멱할 }\end{array}$ & 2008.11 .30 \\
\hline
\end{tabular}

*상기 이슈는 발간 시 상황에 따라 소정 가능

- 기고 논문은 『국제개날협력』의 날간목적에 부합하는 것이어야 한다.

- 기고 논문은 국제협력단이 정하는 “「국제개반협력』원고집필오령”(KOICA 홈페이지에 게시)에 따라야 한다.

- 기고 논문은 다른 학술지에 게재되지 않았으며 게재될 예정이 없는 창작논문이어야 한다.

- 기고 논문은 게재 여부를 분문하고 반환하지 않는다.

\section{2) 심사}

- 심사전차는 『국제개반협력』편집을 위한 국제협력단의 전차에 따라 진행된다.

- 기고 논문의 심사는 국세협력단의 절차에 따르되. 필요에 따라 외니 인사를 위촉할 수 있다. 단, 논문 기고자는 해당 호의 심사자에서 제외된다.

\section{3) 게재}

- 심사를 통과한 원고는 교정·교열을 거쳐 게재한다.

- 게재된 원고에 대해서는 국제협력단에서 정한 기즌에 따라 소정의 원고료를 지급한다.

- 국세협력단 정책연구실은 국ㄱㅅㄱ개발협력』편집 세반규정에 따라 교정 및 수정 등의 편집권한 을 갖는다.

- 원고 게재가 결정된 논문제출자가 별쇄본을 요구할 경우 별도의 비용을 납부해야 한다.

- 게재희망 논문 중 외비의 연구지원을 받은 논문은 그 사실을 밝혀야 한다. 
국 제 개 발 협 력 2008년 제2호

\begin{tabular}{|c|c|c|c|}
\hline 발 & & 행 & 2008년 10월 \\
\hline 발 & 행 & 인 & 박 대 원 \\
\hline 발 & 행 & 처 & 한국국제협 럭단 \\
\hline 편 & 집 & 인 & 정책연구실, 홍보 위원회 \\
\hline 주 & & 소 & $\begin{array}{l}\text { 겅기다. 성남시수정 구 대왕퐌교로 } 418 \\
\text { () 461-833 }\end{array}$ \\
\hline 전 & & 화 & $(031) 740-0301$ \\
\hline 팩 & & $\hat{\imath}$ & $(031) 740-0681$ \\
\hline 홈 & 이 & 지 & www. k oica.go. kr \\
\hline 인 & & 쇄 & 산하기 획인쇄 TEL. (02)2272-5002(代) \\
\hline
\end{tabular}

